Article

\title{
Multilingual Language Mixing and Creativity
}

\author{
Tej K. Bhatia * and William C. Ritchie
}

Department of Languages, Literatures and Linguistics, Syracuse University, Syracuse, NY 13244-1160, USA; writchie@syr.edu

* Correspondence: tkbhatia@syr.edu; Tel.: +1-315-443-5374

Academic Editors: Usha Lakshmanan and Osmer Balam

Received: 14 March 2016; Accepted: 19 April 2016; Published: 16 May 2016

\begin{abstract}
The aim of this paper is to explore a facet of bi/multilingual creativity in language mixing. The first aspect of creativity is driven by the consideration of formal principles, which fall outside monolingual or single language competence, e.g., [1]. The rule-governed mechanism, which allows the integration of the embedded language verbs into the matrix language, is accounted for. This objective is achieved by employing two distinct data sets: (1) grammatical competence (intuitional data) involving the embedded lexical verb mixing in the Light Verb Construction in a variety of languages, particularly in South Asian languages (e.g., Hindi-English); and (2) an experimental data set that exhibits the relationships involved in the generative perspective through consideration of Universal Grammar. The underlying motivation for focusing on India is that language mixing constitutes a grass-roots phenomenon in India since the pre-Christian era; hence it is a stable and time-tested phenomenon which allows us to overcome key methodological issues in the study of language mixing.
\end{abstract}

Keywords: Light Verbs; optimization; bilingual language mixing; language switches; Universal Grammar; Functional Head Constraint; multiple language mixing

\section{Introduction}

The aim of this paper is to explore a facet of bilingual creativity grounded in grammatical competence in language mixing by competent bilinguals. The first part deals with grammatical competence in bilingual language mixing involving a Light Verb Construction (henceforth, LVC). This goal is achieved by employing two distinct data set types-introspective grammatical competency data and experimental data. Perhaps we should mention that we are using the term "language mixing" (henceforth LM) as a cover term for code-mixing and code-switching (see [2] for more details about the distinction we are drawing between code-mixing and code-switching on the one hand and other related phenomena on the other).

In order to overcome certain methodological problems involving LM, the main body of our data is drawn from intuitions concerning the speech patterns of bi/multilinguals from the Indian subcontinent. LM has constituted a grass-roots phenomenon in India since the pre-Christian era; it is a stable, inevitable and time-tested phenomenon. In the usual case, the study of LM faces serious methodological problems for the following reasons. First, the lack of stable bilingualism (e.g., process of creolization). Second, the fact that, in some speech communities, all language-switched sentences are considered to be deviant renders the use of acceptability judgments of the ordinary sort problematic in such communities. Even in areas where LM is accepted, judgments are often inconsistent. Third, the use of natural production as data is subject to well-known problems that arise in general in the use of performance data as the basis for claims about underlying constraints in grammatical knowledge-slips of the tongue and other features of performance that deviate from the rules and principles that constitute underlying competence. Therefore, it is best in research on 
code-switching/LM (a) to choose a community for study in which code-switching is tacitly accepted; and (b) to seek constructions found in that community for careful study that are both peculiar to code-switching on the one hand and for which acceptability judgments are generally consistent on the other.

As pointed out above, LM (both intra-sentential and inter-sentential mixing), is inevitable in the Indian subcontinent. In fact, even if we limit consideration to research on cases of mixing in South Asia involving English as one of the languages, the variety of cases of code-switching that have been studied systematically is impressive. A very brief and incomplete list includes studies of code-switching between Hindi and English [3-8], Marathi and English [9,10], Punjabi and English [11], Tamil and English [12-14], Kannada and English [15], Telugu and English [16] and Bengali and English [17], among others.

Beyond dual LM, multiple LM (in the sense of mixing more than two languages) is also a norm in South Asia. For instance, Bhatia [18] shows how South Asian languages such as Sanskrit (a classical language), Panjabi, and Indian Persian are mixed in advertising to achieve distinct socio-psychological effects. Hindi-English is often mixed with Punjabi to create humor. In another work, Bhatia [19] (pp. 188-189) even shows dialect mixing and its syntactic interface with phonetics, which is a norm in advertising aimed at rural India.

\section{Language Mixing (LM): Matrix vs. Embedded Language}

This section will first introduce the notion of Matrix Language vs. Embedded Language in mixed utterances and then go on to identify three types of verb systems found in South Asian languages-simple verbs, conjunct/Light Verbs and compound verbs. The distinction between Light Verbs and compound verbs is imperative since a (verb + verb) matrix language sequence can occur in monolingual grammars of South Asian languages in compound verb constructions. However, such a combination is not permitted in "Conjunct" / Light Verb constructions (LVCs) in monolingual grammars. Section 2.1 attempts to exemplify three types of verb constructions before underscoring the distinction between monolingual and bilingual grammar with reference to Light Verbs. A later section will detail the creativity of bilinguals while focusing on the LVC in switched verbs and in that it will describe the mechanism underlying Light Verbs in LM and offer a principled explanation toward this end.

\subsection{Light Verbs: Mixed and Single Language Construction}

Before we attempt to account for the structural properties of the LVC in mixed and single language constructions, it is imperative to introduce the distinction between matrix and embedded languages since this distinction is crucial to an understanding of LM (code-switching/mixing), which is the key focus of this paper. Perhaps we should add that such a distinction is motivated by descriptive considerations rather than by theoretical motivations [20].

In most cases of code-switching, it is possible to identify one of the two languages involved as playing a more dominant role than the other. As is customary in much of the code-switching research literature, we will refer to the dominant language in code-switched utterances as the matrix language (ML) and to the non-dominant language as the embedded language (EL). Thus, in example (2), Hindi is the matrix language and English is the embedded language.

1. Monolingual Hindi

$\begin{array}{lllll}\text { vo } & \text { uskii } & \text { arzii-ko } & \text { pasand } & \text { kar-egaa. } \\ \text { he } & \text { his/her } & \text { application-OBJ } & \text { like (N) } & \text { do-will-MAS-SG } \\ \text { 'He will like his/her application.' } & & \end{array}$


2. Code-switched Hindi-English

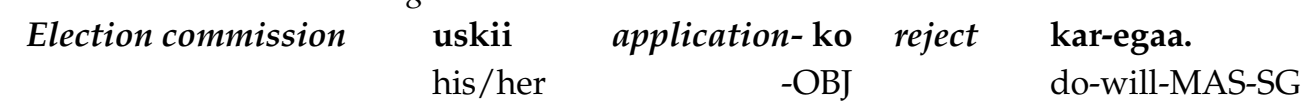

'The election commission will reject his/her application.'

Interestingly, even if English words outnumber Hindi words in (2), in the examples of Hindi-English bilingual mixing Hindi is the matrix language and English is the embedded language in these two-language switched sentences. The matrix language, Hindi, supplies the Tense/Agreement ending. These examples illustrate the LVC in Hindi in which the Hindi verb karnaa 'to do' represents a non-content or dummy verbal element. Such a construction is called a Light/"Conjunct" Verb construction.

In addition to Light Verbs, Hindi and other South Asian languages have two other types of verb constructions, which are termed simple verbs and compound/serial verbs. Sentences (3) and (4) exemplify the case of simple verbs and compound verbs, respectively.

3. Monolingual Hindi: Simple Verb Construction

a. vo kitaab paRh-egaa

he book read-will-MAS-SG

'He will read the book.'

b. * vo kitaab paRh kar-egaa.

he book read do-will-MAS-SG

'He will read the book.'

4. Monolingual Hindi: "Compound" or "Serial" Verb Construction

$\begin{array}{llll}\text { vo } & \text { kitaab } & \text { paRh } & \text { le-egaa. } \\ \text { he } & \text { book } & \text { readta } & \text { take-will-MAS-SG }\end{array}$

'He will read the book (for his benefit).'

Notice in (3b), the use of a dummy/Light Verb karnaa 'to do' with a lexical verb ( $p a R h$ 'read') is not permitted.

While the Tense-Agreement ending (-egaa) is attached to the dummy verb 'do' in (1) and (2), it is attached to a lexical verb ( $p a R h$ 'read') in the simple verb construction as in ( $3 a)$. In the compound verb construction in (4), however, the main verb ( $p a R h$ 'read) is attached to the second verb (le 'take'). In other words, there is a sequence of two lexical verbs. Such a construction is called a compound/serial verb construction. In a compound verb construction, two or more than two lexical verbs are employed ( $p a R h$ 'read' and le 'take'). As is self-evident from the English gloss in (4), the compound verb interpretation is not a mere conjunction of two lexical verbs. The main content in a compound/serial verb construction is rendered by the first verb $\left(\mathrm{V}_{1}\right)$ while the second verb modifies the first verb; in this case it induces an interpretation in which the subject is understood as the beneficiary of the act. The general schema of the compound verb construction is presented in (5) below:

\section{Monolingual Hindi: Compound Verb or Serial Verb Schema}

$\mathbf{V}_{1}$

[Any verb; open set]

paRh 'read'

paRh 'read'

paRh 'read'

paRh 'read'
$\mathrm{V}_{2}$

[restricted set of verbs]

lenaa 'take'

denaa 'give'

baiThanaa 'sit'

Daalnaa 'put into'

\section{Shades of Meaning}

read for one's own benefit read for someone else's benefit read in a sloppy/accidental fashion read aggressively 
The treatment of the compound verb construction in LM is outside the scope of this paper. Instead, we will restrict ourselves to the Light Verb phenomenon. However, what is imperative for the purpose of this paper is to underscore a distinction and contrast between monolingual Compound Verbal clustering on one hand and the code-switched (i.e., language-mixed) verb + verb clustering in bilingual grammar.

\subsection{The Light Verb Construction (LVC)}

Consider now examples (6)-(9).

6. Monolingual Hindi

$\begin{array}{llll}\text { merii } & \text { patnii } & \text { saaRii } & \text { cun-egii } \\ \text { my } & \text { wife } & \text { Saree } & \text { choose-FUT.3.SG.FEM }\end{array}$

'My wife will choose a Saree.'

7. Hindi-English code-switching (illformed)

$\begin{array}{llll}{ }^{*} \text { merii } & \text { patnii } & \text { saaRii } & \text { choose-egii } \\ \text { my } & \text { wife } & \text { Saree } & \text { choose-FUT.3.SG.FEM }\end{array}$

'My wife will choose a Saree.'

8. Monolingual Hindi (illformed)

$\begin{array}{lllll}{ }^{*} \text { merii } & \text { patnii } & \text { [vp saaRii } & \text { cun(-na)] } & \text { kar-egii } \\ \text { my } & \text { wife } & \text { Saree } & \text { choose (INF) } & \text { do-FUT.3.SG.FEM }\end{array}$

'My wife will choose a Saree.'

9. Hindi-English code-switching

\begin{tabular}{|c|c|c|c|c|}
\hline & patnii & Ivp saaRii & choose] & kar-egii \\
\hline my & wife & Saree & choose & UT.3.SG.FEM \\
\hline
\end{tabular}

'My wife will choose a Saree.'

As expected, example (6)—monolingual Hindi-shows no ill-formedness when the Hindi Tense/Agreement element--egii- is suffixed to the Hindi verb stem cun-. Example (7) shows that the Hindi Tense/Agreement element cannot be suffixed directly to the switched English verb choose. Example (9)-we return to (8) in a moment-shows that the presence of the stem of the semantically Light Verb kar-naa 'to do' (underlined) allows the occurrence of the switched verb choose, the Tense/Agreement element -egii being attached to the light-verb stem kar-. As the ill-formedness of example (8) shows, the occurrence of the Light Verb kar-naa is restricted to structures in which the verb has been switched. Note that kar- 'do', like ho- 'be', aa- 'come', and a number of other verbs, lacks the full semantic content of a verb like Hindi cun- or English choose. Jespersen [21], Cattell [22], and others refer to verbs like kar- as "semantically light" or simply "light" verbs. Henceforth, we therefore refer to the construction exemplified by (9) — in which the verb is switched and the Light Verb -kar-occurs as "the Light Verb Construction."

As is well-known, Hindi is not alone among South Asian languages in showing the LVC. As examples (10) and (11) show, this construction is found in cases of code-switching with other South Asian languages as the matrix language.

10. Panjabi-English [11] (p. 129)

\begin{tabular}{|c|c|c|c|c|}
\hline ma & apnii & language & learn & kar-ni \\
\hline I & own & language & learn & do-1.SG.DES \\
\hline
\end{tabular}

'I want to learn my own language.'

11. Tamil-English [12] (p. 21)

\begin{tabular}{|c|c|c|c|c|}
\hline naan & inda & pustagatte & finish & paNNiTTeen \\
\hline I & this & book & finish & doVBP-PERF-PST-1SC \\
\hline
\end{tabular}

'I finished this book.' 
In fact, South Asian languages are not the only ones that exhibit this structure. Consider examples (12)-(15).

12.

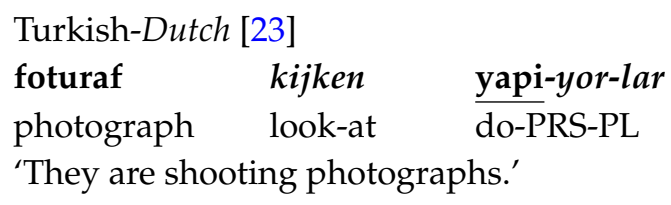

13. Navajo-English [24]

$\begin{array}{llll}\text { Nancy } & \text { bich'i } & \text { show } & \text { anileeh } \\ \text { Nancy } & \text { to.3 } & \text { show } & \text { make.2 }\end{array}$

'You show it to Nancy.'

14. Warlpiri-English [25]

a. grow jarri mi

grow $\quad \overline{\text { become }}$ NNPST

b. hold mani

hold make

'To hold.'

15. Spanish-English [26] (see also Pfaff [27])

$\begin{array}{lllll}\text { Pues ellos } & \text { hacen } & \text { get } & \text { along } \\ \text { Well they } & \text { do.3SG } & \text { get } & \text { along } \\ \text { 'Well they get along.' } & & & \end{array}$

In addition to these language pairs, the following are also reported in the literature as exhibiting this structure (matrix language first): Philippine Creole Spanish-English [28], Philippine Creole Spanish-Tagalog [28], Shona-English [29]. For further examples, see [30], this volume.

\section{3. 'Conjunct' Verbs and the Light Verb Construction (LVC)}

Before proceeding to an analysis of the LVC, we will consider a related construction in Hindi-the structure traditionally termed the 'Conjunct Verb Construction' as exemplified in (16)-(19) below with both monolingual Hindi and code-switched Hindi-English exemplars.

16. Monolingual Hindi

$\begin{array}{lllllll}\text { merii } & \text { patnii } & \text { [NP saaRii } & \text { kii } & \text { pasand] } & \text { kar } & \text {-egii } \\ \text { my } & \text { wife } & \text { Saree } & \text { of } & \text { liking } & \text { do } & \text {-FUT.3.SG.FEM }\end{array}$

'My wife will take a liking to a Saree.'

17. Code-switched Hindi-English

$\begin{array}{lllllll}\text { merii } & \text { patnii } & \text { [NP saaRii } & \text { kii } & \text { choice] } & \text { kar } & \text {-egii } \\ \text { my } & \text { wife } & \text { Saree } & \text { of } & \text { choice } & \text { do } & \text { FUT.3.SG.FEM }\end{array}$

'My wife will choose a Saree.'

18. Monolingual Hindi

$\begin{array}{lllllll}\text { ye } & \text { davaaii } & \text { [AP mujh } & \text { ko } & \text { acchaa] } & \text { kar } & \text {-egii } \\ \text { this } & \text { medicine } & \text { me } & \text { to } & \text { better } & \text { do } & \text { FUT.3.SG.FEM }\end{array}$

'This medicine will make me better.'

19. Code-switched Hindi-English

$\begin{array}{lllllll}\text { ye } & \text { davaaii } & \text { [AP mujh } & \text { ko } & \text { better] } & \text { kar } & \text {-egii } \\ \text { this } & \text { medicine } & \text { me } & \text { to } & \text { better } & \text { do } & \text { FUT.3.SG.FEM }\end{array}$

'This medicine will make me better.' 
The examples in (16)-(19) exhibit the main properties of what is traditionally referred to as the "Conjunct Verb" Construction. In each case an NP or AP functions as the complement of the verb kar-naa. Traditionally, the head of the complement is termed the 'Pre-verb' of the construction and the form of kar-naa is termed the 'Operator Verb.' Hence, we may represent the structures of the sentences in (16)-(17) and (18)-(19) as shown under (20).

20. The Conjunct Verb Construction

$\begin{array}{ll}\underline{\text { Pre-verb }} & \text { Operator Verb } \\ \ldots .[\mathrm{NP} \ldots \mathrm{N}] & \mathrm{kar}+\text { Tense } / \text { Agreement } \\ \ldots \text {. [AP ... A] } & k a r+\text { Tense/Agreement }\end{array}$

Note that ' $\mathrm{N}$ ' may be a deverbal noun, as in examples (1) and (16), suggesting that these monolingual constructions might be equivalent to the bilingual cases in which the complement of kar 'do' is a verb, but this is not the case as the contrast in acceptability in (8) and (16) shows.

Additional Operator Verbs in this construction include other semantically Light Verbs like ho-naa 'to be', ban-naa 'to be made', aa-naa 'to come', paR-naa 'to fall', and de-naa 'to give'.

It might be thought that the kar -construction in (9) above is a straightforward instance of the LVC. However, the grammaticality values of (8) and (9) indicate otherwise. Examples (6-9) are repeated below as (21)-(24), respectively, with relevant structure added for convenience.

21.

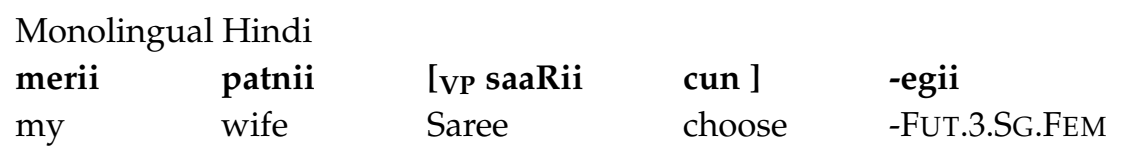

'My wife will choose a Saree.'

22. Hindi-English code-switching

$\begin{array}{lllll}* \text { merii } & \text { patnii } & \text { [VP saaRii } & \text { choose ] } & \text {-egii } \\ \text { my } & \text { wife } & \text { Saree } & \text { choose } & \text {-FUt.3.SG.FEM }\end{array}$

'My wife will choose a Saree.'

23. Monolingual Hindi

$\begin{array}{llllll}{ }^{*} \text { merii } & \text { patnii } & \text { [vp saaRii } & \text { cun (-naa)] } & \underline{\text { kar }} & \text {-egii } \\ \text { my } & \text { wife } & \text { Saree } & \text { Choose (-INF) } & \text { do } & \text {-FUT.3.SG.FEM }\end{array}$

24. Hindi-English code-switching

$\begin{array}{llllll}\text { merii } & \text { patnii } & \text { [vp saaRii } & \text { choose }] & \text { kar } & \text {-egii } \\ \text { my } & \text { wife } & \text { Saree } & \text { choose } & \text { do } & \text {-FUT.3.SG.FEM }\end{array}$

'My wife will choose a Saree.'

As the unacceptability of example (23) indicates, if the "complement" of kar-in these structures is a VP and the head of the "complement" is a Hindi verb, then (unlike the parallel structures in (16) and (18) containing NPs and APs with a Hindi noun or adjective as head) the string is ill-formed. This suggests that the status of kar-in (18)-(19) is quite different from that of kar-in (23). In fact, the complementarity of the distribution of kar- in these structures (it is present only when a switched verb appears) suggests that it is inserted in the course of the derivation of, e.g., (24) to save the derivation from being blocked. This explains the mechanism that makes embedded language verb 'choose' + matrix language dummy verb a very productive process, while the pairing of matrix verb and matrix dummy verb as in (23) is ruled out by the monolingual grammar.

\subsection{Code-Switching and the Light Verb Construction (LVC)}

Let us now turn to a theoretical analysis of the LVC referred to above from the perspective of Chomsky's Minimalist Program [31]. 
In explaining the acceptability values of (21)-(24), we may take (25) as exhibiting the "normal" operation of Verb affixation and formulate the problem of providing a principled account of these data in terms of questions $(26 \mathrm{a}-\mathrm{c})$.

25. Structure for sentences (21)-(24)

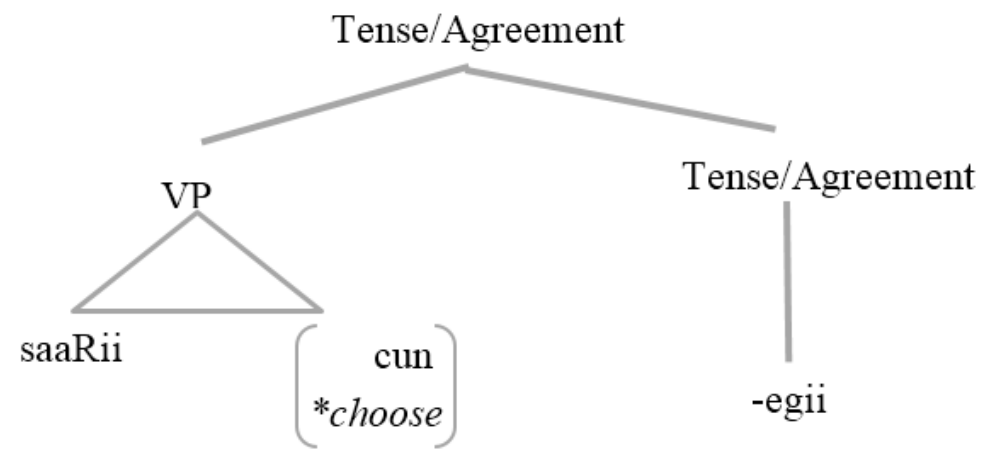

26. Questions

a. Why is the derivation of (22) blocked?

b. Why is the derivation of (24) well-formed?

c. Why is the derivation of (23) blocked?

Adopting standard assumptions in the Minimalist Program concerning "articulated INFL" and its accompanying structure [32] as shown in (25), we take the Numeration of all four sentences in (21)-(24) to include a representation in which the VPs saaRii cun- and saaRii choose are the complements of the functional element Tense/Agreement realized by the suffix -egii as indicated in (25).

What answers does grammatical theory provide for Question (26a) concerning the unacceptability of example (22)? One logical possibility is that the unacceptability of (22) falls under the Free Morpheme Constraint [33]. However, the Hindi-English forms in (27) below, which are quite typical, indicate that this constraint does not operate generally in Hindi.

\section{Hindi-English}

$\begin{array}{lll}\text { a. } & \begin{array}{l}\text { selfish-pan } \\ \text { widow-pan }\end{array} & \text { 'selfishness' } \\ \text { boctor-nii } & \text { 'widowhood' } \\ \text { b. } & \text { 'female doctor' } \\ \text { judge-nii } & \text { 'female judge' } \\ \text { cen-daan } & \text { 'pen holder' } \\ & \text { perfume-daan } & \text { 'perfume bottle' }\end{array}$

A condition that has been proposed and independently justified within the framework of the Minimalist Program [31] that would exclude example (22) is the Functional Head Constraint (FHC) of Belazi, Rubin, and Toribio [34], which is stated as follows: 'The language of the complement f-selected by a functional head, like all other relevant features, must match the corresponding feature of the functional head' [33] (p. 228). The f-selection relation, as characterized by Abney [35] (p. 56), is the syntactic relation between a functional head and its complement. Functional heads include (but are not limited to) complementizers, inflectional elements like tense, aspect, and agreement markers, modal auxiliaries, negative elements, quantifiers, etc. Given the structure in (25) where the functional element -egii f-selects the complement VP containing cun- or choose as its head, and assuming that forms are marked with the grammar from which they originated -egii and cun are marked [+Hindi] and choose is [-Hindi], the FHC excludes the switched form choose in (22) while allowing the unswitched cun- in (21). 
The additional examples in (28)-(30) demonstrate the consistency of the operation of the FHC in the verbal complex of Hindi. The functional heads relevant to the operation of the FHC are the Tense/Agreement element -egii (repeated here for convenience) in the (a) examples, the Modal Aux sak- 'can' in the (b) examples, and the Progressive element -rah-in the (c) examples. In each case the functional head is underlined.

28. Monolingual Hindi

a. merii patnii [vp saaRii cun ] $\frac{\text {-egii }}{\text {-FUT } 3 \text { S }}$

my wife choose $\quad$-FUT.3.SG.FEM

'My wife will choose a Saree.'

$\begin{array}{lllllll}\text { merii } & \text { patnii } & \text { [vp saaRii } & \text { cun ] } & \text { sak } & \text {-tii } & \text { hai } \\ \text { my } & \text { wife } & \text { Saree } & \text { choose } & \text { can } & \text {-3.SG.FEM is } \\ \text { 'My wife can choose a } & \text { Saree.' } & & & \\ \text { merii } & \text { patnii } & \text { [vp saaRii } & \text { cun ] } & \underline{- \text { rah- }} & \text {-ii } & \text { hai } \\ \text { my } & \text { wife } & \text { Saree } & \text { choose } & \text { PROG } & \text {-3.SG.FEM is }\end{array}$

'My wife is choosing a Saree.'

29. Code-switched Hindi-English (without kar)

a.

$\begin{array}{lll}* \text { merii } & \text { patnii } & \text { IVP saaRi } \\ \text { my } & \text { wife } & \text { Saree }\end{array}$

choose] -egii

'My wife will choose a Saree.'

b.

\begin{tabular}{|c|c|c|c|c|c|}
\hline * merii & patnii & [vp saaRii & choose] & sak & $-\mathrm{tii}$ \\
\hline my & wife & Saree & choose & can & -3.SG.FEM \\
\hline \multicolumn{6}{|c|}{ 'My wife can choose a Saree.' } \\
\hline * merii & patnii & [vp saaRii & choose ] & $\underline{\text {-rah- }}$ & $-\mathrm{ii}$ \\
\hline my & wife & Saree & choose & PROG & -3.SG.FEM \\
\hline
\end{tabular}

'My wife is choosing a Saree.'

30. Code-switched Hindi-English (without kar)

a.

merii patnii [vp saaRii

my wife Saree
'My wife will choose a Saree.'

choose]

kar -egii

b.

\begin{tabular}{|c|c|c|c|c|c|c|c|}
\hline merii & patnii & [VP saaRii & choose] & kar & $\underline{\text { sak }}$ & - tii & hai \\
\hline my & wife & Saree & choose & do & can & -3.SG.FEM & is \\
\hline \multicolumn{8}{|c|}{ ‘My wife can choose a Saree.' } \\
\hline merii & patnii & [vp saaRii & choose] & kar & -rah- & $-\mathrm{ii}$ & hai \\
\hline my & wife & Saree & choose & do & PROG & -3.SG.FEM & is \\
\hline
\end{tabular}

We turn now to question (26b) — why is example (24) well-formed? We propose that the grammar of Hindi includes an operation that inserts the Light Verb kar- as the carrier of the Tense/Agreement element-egii, thereby neutralizing the functional character of -egii. This operation, then, acts as a Last Resort to save a derivation that would otherwise be blocked by the FHC. Thus, this operation is analogous to Chomsky's independently motivated analysis of the do-support phenomenon in English [31] and in accordance with a general condition on Last Resort as characterized in Chomsky [31], however these conditions are ultimately formulated. That is, a step in a derivation (e.g., do-insertion) is legitimate only if it is necessary for well-formedness (that is, had the step not been taken, the derivation would not have been well-formed). 
Question (26c) - that concerning the ill-formedness of (23) - has a natural answer within Chomsky's Economy Framework [31]; see [16]. Because the derivation of (23) is well-formed without the application of kar -insertion, that operation cannot apply in its derivation in accordance with Chomsky's economy conditions on derivations as described above.

Summarizing, the phenomena exemplified in (21)-(24) receive a natural account within Universal Grammar under Minimalist assumptions. Of course, the Functional Head Constraint as formulated here is not the only formal mechanism to account for this innovation in bilinguals, other approaches are also possible. One such approach is proposed by Myers-Scotton's matrix language frame (MLF) model [29] (p. 82); however, an analysis based on such an approach is subject to serious limitations; for more details see [1]. One cannot exclude the possibility that the Minimalist Program framework proposed by MacSwan $[20,36]$ can rule out any constraint to the mixed system. However, any approach or a framework of analysis has to account for the following two-step mechanism of permitting the integration of the Embedded Language verb into the bilingual grammar of Hindi-English bilinguals.

\section{Two-Step Mechanism}

Step 1: The Embedded Language verb appears in its stem form

Step 2: The dummy verb from the Matrix language ( $\underline{-d o}$ insertion) is subject to Tense/Agreement marking.

Even verbs such as 'to look down upon' undergo the same process.

32. Hindi-English

$\begin{array}{llllll}\text { kissii } & \text { par } & \text { bhii } & \text { look down upon } & \text { na } & \text { kiijiye } \\ \text { someone } & \text { on } & \text { even } & & \text { not } & \text { do-POL. IMP. }\end{array}$

'Please do not look down upon any one.'

\section{Second Language Acquisition and Switched Light Verbs: Experimental Data Set}

As shown from the discussion above, the use of embedded verbs in the LVC in Hindi-English code-switching set in motion (verb + verb) (unlike the serial verb as in sentence 4 ) and thus, adds a new dimension of creativity not permitted by the monolingual grammar. Such creativity cannot be treated simply as a language contact or sprachbund phenomenon. Of course, language contact is a prerequisite but not a sufficient condition for the following two reasons: (1) As shown in examples (12)-(14) the Light Verb switching mechanism is witnessed in genetically unrelated languages; (2) As shown by the results of our experimental data-reported below, even minimal language contact leads to this phenomenon and is thus driven by the consideration of UG and innateness.

In view of the fact that the LVC is found in such a wide variety of dissimilar language pairs, the question arises as to whether the principles that determine the structure are innate- that is, whether we can find evidence for a "poverty of the stimulus" argument for its innateness.

In order to explore this possibility, we conducted two studies (as reported in [1]) of adult second language learners who had had no experience with LM to see if their grammaticality judgments matched those given in (28)-(30) above.

In the first study, 42 undergraduate students at a medium-sized university in the Northeast US, who had studied Hindi in the classroom for a maximum of one year were given pairs of sentences and asked to judge which member of the pair was more grammatical or "correct" than the other. Each pair consisted of either (1) two monolingual sentences; or (2) two sentences with code-switched verbs. In each case, one of the sentences contained the Hindi Light Verb kar and the other sentence did not contain this verb. There were 12 items.

The results were as shown in Table 1. 
Table 1. Overall Group Results.

\begin{tabular}{ccc}
\hline & Preference for Sentence without -kar & Preference for Sentence with -kar \\
\hline Monolingual sentences & $438(87 \%)$ & $66(13 \%)$ \\
\hline $\begin{array}{c}\text { Sentences containing a } \\
\text { code-switched Verb }\end{array}$ & $43(9 \%)$ & $461(91 \%)$ \\
\hline
\end{tabular}

Results in the first cell (87\%; e.g., for sentences such as 8 and 23) and cell 4 (91\%; e.g., for sentences such as 9 and 24) indicate that second language learners' grammaticality judgments are remarkably similar to the monolingual grammar as well as code-switched bilingual grammars.

Since the subjects had not been exposed to code-switching at all (much less the specific structures involved-the LVC in the cases reviewed above), the results indicate a classic case of the poverty of the stimulus. The subjects exhibit a knowledge of principles (the Functional Head Constraint and Economy of Derivation) that they could not have attained from their experience with the languages involved and, hence, the knowledge in question must be part of the a priori, innate cognitive structure that they bring to the task of language learning.

In the second study in order to test the questionnaire, we gave it to five native speakers of English who were advanced learners of Hindi at a second university in Upstate New York. Their judgments accorded with those of the subjects in the first study.

For further details of the design, execution and discussion of these studies, see [1] (pp. 53-56).

\section{Conclusion}

LM is a salient property of the bi/multilingual mind, which triggers bilingual linguistic creativity in terms of creating both new structures and new meanings [37]. We have attempted to show a three-way verbal typology-simple verbs, the LVC ("conjunct") and serial verbs (also known as, "Compound Verbs") - in South Asian languages, particularly Hindi. We argue that the (verb + verb) structure witnessed in the code-switched grammar of balanced Hindi-English bilinguals (that is, the LVC) is qualitatively different from the monolingual co-occurrence of (verb + verb) involving Light Verbs. The bilingual grammar triggers a new phenomenon, which requires the use of dummy verbs such as karnaa 'to do' with switched embedded-language verbs drawn from English. The monolingual grammar on the other hand blocks the (verb + verb) pattern if both the lexical verb and the dummy verb are drawn from the matrix language. The mechanism of code-switched Light Verbs in bilingual and trilingual mixing is accounted for and a theoretical explanation is offered in terms of the Functional Head Constraint and Economy of Derivation. Our findings are further attested by experimental data obtained from English learners of Hindi as a second language showing code-switched lexical verbs induce a generative process which optimizes the grammatical resources of bilinguals through the LVC and is grounded in the innate principles of Universal Grammar. However, in light of the discussion in the section below, we should hasten to qualify that the role of typological and/or other specific characteristics of languages including the role of the matrix language cannot be ruled out.

\section{Challenges and Future Research}

When we examine LM from the perspective of trilingual LM, particularly in South Asian languages, and its interface with the matrix and embedded language, a number of interesting observations emerge, which pose future challenges for the grammar of LM.

Interestingly, according to Lakshmanan (personal communication) [38] when the matrix language is Hindi, trilingual mixing among Hindi-Tamil-English exhibits a strong tendency toward using the English verbalizing suffix-ify or -ofy with Tamil verbs (instead of the embedded language verb stem) and inserting the light verb -karnaa 'to do' as in (33) and (34a). Without the insertion of -ify and karnaa, ungrammatical output is generated (34b). However, suffixing -ify with an embedded English verb such as choose is blocked in Hindi-English bilingual grammar as is evident by the ungrammaticality of (35). 
33.

Hindi-Anglicized Tamil (Adapted from [39]) (Matrix language-Hindi)

$\begin{array}{llll}\text { tum } & \text { tanni } & \text { kudicci-ify } & \text { kar-o } \\ \text { you } & \text { water } & \text { drink-Eng vsuffix } & \text { do-2IMP } \\ \text { 'You drink water (IMP).' } & & \end{array}$

34.

Hindi-Anglicized Tamil [38]; (Matrix language-Hindi)

a.

Main tanni

kudicci-ify

karuungii

I water

drink-VBP-Eng suffix

do-FUT.1FEM.SG

b.

'I will drink water'.

* main tanni

kudic

karuungii

I water

drink suffix

do-FUT.1FEM.SG

'I will drink water'.

35.

\begin{tabular}{lllll}
\multicolumn{2}{l}{ Hindi-English } & (Matrix language-Hindi) & & \\
* merii & patnii & saaRii & choose-ify & karegii \\
My & wife & saree & choose-vsuffix & do-fut.3FEM. SG \\
'My wife will choose a Saree'. & &
\end{tabular}

As pointed out above, sentences ( 33 and 34a) without the insertion of the light verb -kar would result in an ungrammatical output (34b), which lends further support to the two-step mechanism presented in (31). The only difference is that in trilingual grammar the verbal stem undergoes an additional step of -ify,-ofy or -ing verbal suffixation particularly in South Asia; and thus shows variation. Perhaps we should mention that Tamil and Hindi belong to genetically distinct groups; Tamil belongs to the Dravidian language family whereas Hindi is an Indo-European language. Perhaps the use of verbal suffixation is the result of a language-specific contact situation. However, the verbal stem-ify etc. are not compatible with the English verb choose, since the verb and the verbalization suffix cannot be drawn from the same language. In contrast, Hindi-English bilingual grammar does not employ the -ify suffixation strategy. This explains the ungrammaticality of (35) and the variability of mixing with light verbs in monolingual, bilingual and trilingual grammars (33 and 34a). In spite of the variation, Step 2 (light verb insertion and Tense-Aspectual marking from the same language) is valid.

Now let us turn to the question of the light verb insertion in bilingual Hindi-English grammar if English is the matrix language instead of Hindi.

36. English-Hindi (English as a matrix language)

a. my wife will be cun-ing/cun-ify some Sarees. choose

'My wife will be choosing/will choose some Sarees.'

b.

\section{* my wife will cun some Sarees.}

choose

'My wife will choose some Sarees.'

37. Monolingual English

a. $\quad$ * My wife will do choose some Sarees. (Light verb insertion-do is blocked)

b. My wife will do some choosing of Sarees.

Since, as the matrix language, English primarily lacks the LVC, a Hindi verb is subjected to the rules of the matrix language English. Light Verb insertion is not required overtly, as is evident from the ungrammaticality of (37a). In contrast, the grammaticality of (37b) lends some support for the presence of a 'ghost' Light Verb 'to do'. In addition to the verbal marking -ing on Hindi verbs, other English verbalizing markers for nouns (-ify or -ofy) are also used as illustrated by (36a). Their absence yields an 
ungrammatical sentence as in (36b). Whether or not these three suffixes (-ing; ify-, and -ofy) incorporate a 'ghost' light verb, is the subject of future research. For a treatment of verbal suffixation see [7].

Furthermore, the variability in the use of LVCs across sociolinguistic contexts (see [26,39-41]) is another noteworthy area of future research. Therefore, no claims are being made in this paper that the LVC (in spite of its sensitivity to Universal Grammar) will be attested in all languages in an invariable way.

Acknowledgments: We are grateful to Professors Usha Lakshmanan and Osmer Balam, and to other anonymous reviewers for their comments and suggestions on an earlier version of this paper.

Conflicts of Interest: The authors declare no conflict of interest.

\section{Symbols and Transcription}

In Hindi examples, capital letters refer to retroflex consonants. A long vowel is represented vowel repletion.

$\begin{array}{ll}1 & \text { 1st person } \\ 2 & \text { 2nd person } \\ 3 & \text { 3rd person } \\ \text { COMP } & \text { Complementizer } \\ \text { FEM } & \text { Feminine } \\ \text { FHC } & \text { Functional Head Constraint } \\ \text { IMP } & \text { Imperative } \\ \text { INF } & \text { Infinitive } \\ \text { MAS } & \text { Masculine } \\ \text { PERF } & \text { Perfective } \\ \text { POL } & \text { Polite } \\ \text { PL } & \text { Plural } \\ \text { PROG } & \text { Progressive } \\ \text { PST } & \text { Past } \\ \text { SG } & \text { Singular } \\ \text { VBP } & \text { Verbalizing Participle } \\ \text { VEng } & \text { Verbalizing English (suffix) }\end{array}$

\section{References}

1. Bhatia, T.; Ritchie, W. Language Mixing, typology, and second language acquisition. In The Yearbook of South Asian Languages and Linguistics; Sage: London, UK; Delhi, India, 2001; pp. 37-62.

2. Bhatia, T., Ritchie, W., Eds.; Bilingual Language Mixing, Universal Grammar, and second language acquisition. In Handbook of Second Language Acquisition; Academic Press, Inc.: San Diego, CA, USA, 1996; pp. 627-688.

3. Kachru, B. Toward structuring code-mixing: An Indian perspective. Int. J. Sociol. Lang. 1978, 16, 28-46. [CrossRef]

4. Gumperz, J. Discourse Strategies; Cambridge University Press: Cambridge, UK, 1982.

5. Singh, R. Grammatical constraints on code-mixing: Evidence from Hindi-English. Can. J. Linguist. 1985, 30, 33-45.

6. Pandit, I. Hindi English Code Switching: Mixed Hindi English; Datta Book Centre: Delhi, India, 1986.

7. Bhatia, T. Bilinguals' creativity and syntactic theory: Evidence for emerging grammar. World Engl. 1989, 8, 265-276. [CrossRef]

8. Bhatt, R. Code-switching, constraints, and optimal grammars. Lingua 1997, 102, 223-251. [CrossRef]

9. Joshi, A. Processing of sentences with intrasentential code switching. In Natural Language Parsing: Psychological, Computational, and Theoretical Perspectives; Dowty, D., Karttunen, L., Zwicky, A., Eds.; Cambridge University Press: Cambridge, UK, 1985; pp. 190-205. 
10. Pandharipande, R. Formal and functional constraints on code-mixing. In Codeswitching as a Worldwide Phenomenon; Jacobson, R., Ed.; Peter Lang: New York, NY, USA, 1990; pp. 15-31.

11. Romaine, S. Bilingualism; Blackwell: Oxford, UK, 1989.

12. Annamalai, E. Lexical insertion in a mixed language. In Papers from the Seventh Regional Meeting of the Chicago Linguistic Society; Adams, D., Campbell, M.A., Cohen, V., Lovins, J., Maxwell, E., Nygren, C., Reighard, J., Eds.; The Chicago Linguistic Society: Chicago, IL, USA, 1971; pp. 20-27.

13. Annamalai, E. The Anglicized Indian languages: A case of code mixing. Int. J. Dravid. Linguist. 1978, 7, 239-247.

14. Annamalai, E. The language factor in code mixing. Int. J. Sociol. Lang. 1989, 75, 47-54. [CrossRef]

15. Sridhar, S. On the functions of code-mixing in Kannada. Int. J. Sociol. Lang. 1978, 16, 109-177. [CrossRef]

16. Bandi-Rao, S.; den Dikken, M. Light switches: On V as a pivot in codeswitching, and the nature of ban on word-internal switches. In Grammatical Theory and Bilingual Codeswitching; MIT Press: Cambridge, MA, USA, 2014; pp. 161-183.

17. Chatterjee, T. Structural changes in Bengali-English verbs through the exploration of Bengali films. Languages 2016. [CrossRef]

18. Bhatia, T. English in advertising: Multiple mixing and media. World Engl. 1987, 6, 33-48. [CrossRef]

19. Bhatia, T. Advertising and Marketing in Rural India; New Delhi: Macmillan, India, 2007.

20. MacSwan, J. Code-Switching and grammatical theory. Handbook of Bilingualism and Multilingualism; Wiley Blackwell: Oxford, UK, 2013; pp. 323-350.

21. Jesperesen, O. A Modern English Grammar on Historical Principles; George Allen: London, UK; Unwin Ltd.: London, UK; Ejnar Munksgaard: Copenhagen, Danmark, 1954.

22. Cattell, R. Complex Predicates in English; Academic Press Australia: North Ryde, Australia, 1984.

23. Boeschoten, H.; Verhoeven, L. Integration niederländischer lexikalischer Elemente ins Türkische: Sprachmischung bei Immigranten der ersten und zweiten Generation. Linguist. Ber. 1985, 98, 347-364.

24. Canfield, K. A note on Navajo-English code-mixing. Anthropol. Linguist. 1980, 22, 218-220.

25. Bavin, E.; Shopen, T. Warlpiri and English: Languages in contact. In Australia, Meeting Place of Languages; Clyne, M., Ed.; Department of Linguistics, Australia National University: Canberra, Australia, 1985; pp. 81-94.

26. Balam, O. Code-switching and linguistic evolution: The case of 'Hacer $+V^{\prime}$ ' in Orange Walk, Northern Belize. Leng. Mig. 2015, 7, 83-109.

27. Molony, C. Recent relexification processes in Philippines Creole Spanish. In Sociocultural Dimensions of Language Change; Blount, B., Sanches, M., Eds.; Academic Press: New York, NY, USA, 1997; pp. 131-159.

28. Pfaff, C. Functional and structural constraints on syntactic variation in code-switching. In Papers from the Parasession on Diachronic Syntax; Steever, S., Walker, C., Mufwene, S., Eds.; Chicago Linguistic Society: Chicago, IL, USA, 1976; pp. 248-259.

29. Myers-Scotton, C. Duelling Languages: Grammatical Structure in Codeswitching; Clarendon Press: Oxford, UK, 1993.

30. Muysken, P. From Colombo to Athens: Real and universalist perspectives on bilingual compound verbs. Languages 2016. [CrossRef]

31. Chomsky, N. The Minimalist Program; MIT Press: Cambridge, MA, USA, 1995.

32. Pollock, J.-Y. Verb movement, Universal Grammar, and the structure of IP. Linguist. Inq. 1989, 20, 365-424.

33. Sankoff, D.; Poplack, S. A formal grammar for code-switching. Pap. Linguist. 1981, 14, 3-45. [CrossRef]

34. Belazi, H.M.; Rubin, E.J.; Toribio, J. Code switching and X-bar theory: The Functional Head Constraint. Linguist. Inq. 1994, 25, 221-237.

35. Abney, S. The English Noun Phrase in Its Sentential Aspect; MIT: Cambridge, MA, USA, 1987.

36. MacSwan, J., Ed.; Grammatical Theory and Bilingual Codeswitching; MIT Press: Cambridge, MA, USA, 2014.

37. Bhatia, T.K.; Ritchie, W.C. The Bilingual Mind and Linguistic Creativity. J. Creat. Commun. 2008, 3, 5-21. [CrossRef]

38. Lakshmanan, U.; Southern Illinois University, Carbondale, IL, USA. Personal communication, 02 February 2016.

39. Shanth. Creolisation or Code Switching. Available online: http://towardstengen.blogspot.com/2005/09/ creolisation-or-code-switching.html (accessed on 20 February 2016). 
40. Balam, O.; Prada Pérez, A.; Mayans, D. A Congruence approach to the study of bilingual compound verbs in northern Belize contact Spanish. Span. in Cont. 2014, 11, 243-265. [CrossRef]

41. Jenkins, L.D. Bilingual verb constructions in southwestern Spanish. Biling. Review. 2003, 27, 195-203.

(C) 2016 by the authors; licensee MDPI, Basel, Switzerland. This article is an open access article distributed under the terms and conditions of the Creative Commons Attribution (CC-BY) license (http://creativecommons.org/licenses/by/4.0/). 